\title{
Effects on exercise and fitness outcomes of workplace physical activity interventions targeting older employees: A systematic review and meta- analysis
}

\author{
Dafna Merom ( $\nabla$ d.merom@uws.edu.au ) \\ Western Sydney University https://orcid.org/0000-0001-6459-8628 \\ Fiona Stanaway \\ The University of Sydney School of Public Health \\ Joanna J Sweeting \\ The University of Sydney School of Rural Health \\ Anne Tiedemann \\ The university of Sydney School of Public Health \\ Shirin J Mumu \\ Western Sydney University \\ Klaus Gebel \\ University of Technology Sydney \\ Ding Ding \\ The University of Sydney School of Rural Health
}

Research article

Keywords: older employees, exercise, health, workplace, interventions, systematic review, meta-analyses, randomised controlled trials

Posted Date: November 8th, 2019

DOI: https://doi.org/10.21203/rs.2.17006/v1

License: (9) (7) This work is licensed under a Creative Commons Attribution 4.0 International License. Read Full License 


\section{Abstract}

Background: "Active Ageing" policy to delay retirement mean that maintaining the health and fitness of older employees has become increasingly important. This systematic review summarises the characteristics and effect on exercise and fitness outcomes of workplace physical activity (PA) interventions targeting older employees. Methods: Five online databases were searched from inception to December 2018. Eligible studies were of any experimental design, included employees aged $\geq 50$ years, had PA as an intervention component and reported PA-related outcomes. Results: Titles and abstracts of 7470 records were screened and 16 unique interventions were included (3,215 participants). Eleven studies were RCTs. Six interventions targeted multiple risk factors ( $\mathrm{n}=1,586)$ involving screening for cardiovascular disease risk factors, but had a non-specific description of the PA intervention. Four interventions targeted nutrition and PA $(n=1,127)$, and six intervention ( $n=195)$ focused only on PA. Seven interventions were short -term ( $<15$ weeks), six interventions lasted 6-9 months and three interventions were long-term (10-12 months). Interventions overwhelmingly targeted aerobic PA compared to strength, balance and flexibility. No studies involved screening for falls/injury risk. Computation of effect sizes (ES) was only possible in a maximum of three RCTs per outcome. ESs were statistically non-significant for all outcomes. ESs were medium for PA behaviour ( $E S=0.2595 \% \mathrm{Cl}:-0.07$ to 0.56$)$, muscle strength ( $E S=0.27,95 \% \mathrm{Cl}:-0.26-0.80)$, cardiorespiratory fitness ( $E S=0.28,95 \% \mathrm{Cl}:-22$ to 0.78$)$ and flexibility $(E S=0.50,95 \% \mathrm{Cl}:-0.04-1.05)$ and large for balance (ES=1.29, $95 \% \mathrm{Cl}:-0.56-3.15)$. GRADE criteria-rated quality of evidence were 'low' due to high risk of bias, imprecision and inconsistency. Conclusions: The effect of workplace interventions for improving fitness outcomes of older employees is uncertain. There is a need for high-quality PA interventions that takes into account the broader PA recommendations for older adults. Such interventions should incorporate strength and balance training and screening of falls/injury risk in multi risk factors approaches.

\section{Background}

Population ageing poses individual, social, economic and political challenges and is predicted to accelerate even further in the $21^{\text {st }}$ century [1]. The WHO's "Active Ageing" concept is a leading global policy strategy for successful ageing [2], particularly influencing retirement policies towards maintaining engagement with paid employment. In Europe and other developed countries strategies have been implemented to promote economic activities among aged workers, including incentives for late retirement, penalties for early retirement, and an increase in the age of mandatory retirement [3]. Delayed retirement means that more employees beyond the age of 55 years will remain in the workforce [4].

Because of age-related decline, an older workforce requires special considerations regarding occupational health, safety and productivity [5]. An in-depth review by Crawford et al. [6] identified a number of physiological and psychological differences between older workers and their younger counterparts, including reduced muscle strength, endurance, trunk flexibility, balance, aerobic capacity (particularly in women), tolerance to heat, increased anthropometric risks, psychological exhaustion, anxiety and depression. Further, older employees suffer from greater prevalence of comorbidities, and more musculoskeletal problems, sickness-related absence and fatal injuries [6].

It is well established that regular physical activity (PA) is effective in attenuating age-related physiological decline in all body systems, and preventing and managing many age-related chronic and musculoskeletal conditions [7-9]. Hence, maintaining good PA habits is likely to benefit older employees, in terms of health as well as work productivity and safety. The workplace has long been considered a good setting for health promotion as most adults attend work for most of their waking hours. Hence, many PA interventions have been conducted in the workplace, with a first systematic review of their effectiveness published in 1998 [10]. However, we did not identify any systematic reviews of workplace PA interventions that addressed the specific needs of older employees in terms of their physiological or safety needs. Interventions that specifically promote muscle mass, strength, and balance are important for the prevention of sarcopenia, functional disabilities, falls and injuries, and are now part of PA recommendations for older adults worldwide [11]. One recent systematic review synthesised the evidence on health promotion interventions targeting older employees [12]. However, this review examined a variety of health promotion initiatives and may have missed interventions that focused on PA, considering that only two keywords, "fitness" and "capacity", were used to capture PA promotion. Given PA recommendations for older adults include a range of physical outcomes relevant to health beyond cardiorespiratory fitness/capacity, such as muscle strength, balance and flexibility $[13,14]$, it is important to include broader terms when reviewing health promotion programs. Furthermore, the main outcomes included in the review by Poscia et al. were health status, wellbeing and work productivity, not PA measures. Thus, the effectiveness of workplace interventions on PA and other fitness domains of older employees is uncertain.

The aims of this systematic review were to: i) identify and characterise workplace PA interventions delivered to employees aged $\geq 50$ years; ii) assess the methodological quality of the studies; iii) assess the effect of interventions on PA and fitness outcomes highlighted in PA recommendations for older adults.

\section{Methods}

This review followed guidance published by the Centre for Reviews and Dissemination, the Cochrane Collaboration [15], and PRISMA guidelines [16] (see Supplementary file 3) and was prospectively registered with the International Prospective Register of Systematic Reviews (PROSPERO; registration number CRD42018084863 available at https://www.crd.york.ac.uk/prospero/display_record.php?RecordID=84863)

\subsection{Inclusion and exclusion criteria}

We included studies that involved PA interventions delivered at workplaces to employees aged $\geq 50$ years. Studies that included a wider age range were eligible for inclusion if the mean age of participants was at least 50 years. Interventions could include those related to aerobic PA (e.g., walking), stretching, balance, muscle strength, yoga, tai chi, Pilates, gym workout, sport or any other form of PA/exercise. Studies that targeted other health behaviours in addition to PA were only included if PA was one of the key components of the intervention and a PA outcome was reported. Studies with any experimental design (prepost with or without a comparison group, nonrandomised trials, RCTs and cluster RCTs) were included because of the small number of randomised controlled trials (RCT) anticipated based on a previous review [12]. 
Studies were excluded if the PA intervention targeted older employees, but was not delivered in the workplace (e.g., community, health practice), or if the interventions targeted the whole workplace with a wider age range and did not include specific PA outcomes for the sub-group of older employees.

\subsection{Search strategies}

Five databases were systematically searched from inception to the end of 2018: Medline, PreMedline, Psyclnfo, CINAHL, and the Cochrane Controlled Register of Trials (CENTRAL). Specific search strategies were developed for each database, using a combination of text terms and subject headings where applicable. All electronic searches included MeSH terms and keywords for workplace (e.g. occupations, worksite), PA (e.g., walking, postural balance, muscle strength) and intervention (e.g., health promotion, program, RCT) and were limited to humans, and age (Psyclnfo 40+ all other 45+). The MeSH terms and keywords are presented in Appendix 1. One reviewer (JS) screened the titles and abstracts to identify potential papers for inclusion as well as running forward and backward citation tracking of potential studies selected for full text review. Two reviewers (JS, DM) independently conducted the final selection of papers based on full text. Disagreements were discussed and resolved by consensus.

\subsection{Data extraction}

Three data extraction formats were used: A table summarising the included studies was created using the subheadings source, study design, population characteristics, study duration, type of intervention, comparison group, and outcomes. A second table to address research aim 1 described characteristics of each intervention in terms of recruitment, content, intervention deliverer and process outcomes based on data extracted by DM and SM. A third table summarised the quality of the included papers based on the Cochrane risk of bias tool for RCTs and additional domains from the Robins tool for nonrandomised studies with a comparison group [15]. The domains included randomisation sequence generation, allocation concealment, blinding of participants and personnel, blinding of outcome assessment, incomplete outcome data and selective outcome reporting. The first two domains were only assessed in RCTs. In non-randomised studies with a control group the additional domains of confounding and selection bias were assessed.

\subsection{Quality assessments and analysis}

Each domain was assessed independently by two authors (MD, FS) who assigned a judgment of either 'low', 'high' or 'unclear' risk of bias. Disagreement was resolved by consensus or, where needed, by consultation with a third reviewer (DM). We used Comprehensive Meta-Analysis software (Version 2, Biostat, Englewood, New Jersey, USA) to conduct random effects meta-analyses for each outcome where sufficient homogeneity between studies would allow for meaningful quantitative synthesis. The standardised mean difference (SMD) (Hedges' g) was calculated for each meta-analysis, standardised by postscore SD (or its estimate) and calculated using the premean and postmean and SD or, when this was unavailable, the mean change score. Effect sizes were categorised as small $(0.20)$, medium $(>0.20-0.5)$ or large (0.8 or greater) [17]. For trials of effectiveness of change in moderate-to-vigorous minutes of PA we used data from accelerometers when possible, otherwise self-reported data. When energy expenditure was reported as kilocalories per week, we converted the value to minutes engaged in at least moderate-intensity activity using the population mean body weight and 4 Metabolic Equivalents for Task (METs) as at least moderate-intensity exercise. Statistical heterogeneity was determined by the $\mathrm{I}^{2}$ and $\chi^{2}$ tests. Finally, we used the Grading of Recommendations Assessment, Development and Evaluation (GRADE) approach to rate the overall quality of evidence for each outcome from 'very low' to 'high'[18, 19], including a narrative summary of findings for outcomes without meta-analysis [19]. GRADE ratings are based on the domains of risk of bias in included studies, indirectness of evidence, imprecision, inconsistency and likelihood of publication bias.

\section{Results}

\subsection{Study selections and characteristics}

Our search resulted in 7470 records which were screened by title and abstract. Of these, 59 were further assessed for eligibility based on full text (Figure 1). Seventeen studies met the inclusion criteria, however, two publications referred to the same intervention [20, 21], resulting in 16 unique interventions.

The characteristics of the studies are summarised in Table 1. Nine studies were randomised controlled trials (RCTs) [21-29], and two were cluster RCTs - one involving only two worksites [30] and the other several university units [31]. There were also two non-randomised studies [32, 33] three pre-and postevaluations with no comparison group [34-36].

\subsection{Participants}

In total, 3,215 participants (of those 2045 participated in RCTs) were included in the 16 worksite PA interventions: five in the USA [22-25, 31], two in the UK [27, 34], and one each in Taiwan [33], Japan [32], Poland [26], Australia [35], the Netherlands [20, 21], Switzerland [30], Canada [28], Sweden [29] and Italy [36].

Four interventions were delivered in academic institutions [22, 26, 28, 31], three in hospitals or medical centres [21, 25, 36], and four were delivered to factory employees [27, 32-34]. One intervention was delivered to transport workers (drivers) [35] and three interventions were delivered to office workers [24, 29, 30]. Most studies ( $n=12)$ targeted both genders, with a high percentage of male participants $(>60 \%)$ in transport [35] and IT workplaces [24], and fewer male participants $(18 \%-25 \%)$ in academic/ administrative [22] and medical occupations [21,28]. Three interventions targeted females only [23, 25, 26] and one males only [32].

\subsection{Characteristics of PA interventions}

\subsubsection{PA types and fitness domain}


Table 2 summarises intervention characteristics (for more details see Supplementary Table 1). Six studies addressed multiple cardiovascular risk factors [22, $24,25,31,33,34]$, four targeted PA and nutrition [21, 32, 35, 36] and six focused only on PA [23, 26-30]. Interventions overwhelmingly focused on aerobic PA compared to other domains relevant for older people such as balance, strength and flexibility. In all multiple risk factor interventions some form of 'risk assessment' was applied before the targeted behaviour was chosen by or for participants, such as a nurses' check-up for CVD risks [34] or self-appraisal of risk using questionnaires [22, 24], or assessment carried out during the first educational session [33]. However, none of the risk factor assessments considered screening risk factors specific to older people such as falls and injuries. In addition, nearly all of these multiple risk factor studies used a generic description of the PA intervention, such as 'exercise on their own' [31], 'exercise training' [25], referrals to exercise classes [34], or choosing PA goals [22, 24]. In the multiple risk factors studies by Hughes et al. [22] and Low et al. [25] the interventions also offered on-site self-managed activities such as walking groups or using worksite facilities. The dual PA and nutrition interventions focused on aerobic regimens such as steps accumulation [21, 32, 35], counselling to shape PA goals [36] or an aerobic workout on site [21]. The study by Strijk et al. [21] also offered yoga sessions, an activity that is recognised as multi-dimensional and enhances muscle strength, balance, and mobility [37]. The PA-only interventions focused either on aerobic regimens such as use of a treadmill workstation [29], self-managed aerobic walking [27] or Nordic walking [26] as well as non-aerobic fitness domains, such as multi-dimensional PA (tai-chi) [38], and progressive strength and balance exercises [30]. Nordic walking is primarily aerobic activity that may increase upper body strength and flexibility, hence, these domains were marked as well in Table 2 [26].

\subsubsection{Delivery modes}

Three delivery modes were noted (Table 2). In seven studies the PA was delivered on site during working hours [21, 23, 25, 26, 29, 30], or on site but before working hours [28], in five studies participants were counselled in the workplace in face-to-face meetings [31-33], or by telephone calls (COACH-arm) [22], or a combination of both [36], but the PA sessions took place in employees' discretionary time. In four studies the PA was self-managed with little or no supervision $[24,27,34,35]$. The study by Hughes et al. [22] had two intervention arms; one involved personal contact with students trained in behaviour change coaching ("COACH"), while the other arm was self-managed through a web-based intervention ("RealAge") with no other contact [22]. The study by Cook et al. [24] was also a web-based self-managed intervention (HealthyPast50).

\subsubsection{Intervention duration}

Seven interventions were short-term, ranging from 6 to 15 weeks $[23,24,26-28,30,35]$. Six interventions lasted between 6 and 9 months [21, 25, 32-34, 36], and three interventions lasted up to 13 months [22, 29, 31]. All studies provided data related to intervention retention rates (i.e., withdrawals) with the exception of one pre-post study [34]. Not all studies reported intervention compliance (e.g. attendance at classes, recorded logs) and a few reported on program fidelity.

\subsubsection{Intervention reach}

Program reach (i.e., proportion of study population recruited to the trials) varied substantially. When recruitment methods involved a targeted strategy (TS) based on prior 'screening or eligibility criteria', a strategy reported in five studies [27, 32-34, 36], intervention reach was highly variable. In the Japanese study $92 \%$ of the targeted eligible employees were recruited [32], while two interventions in the UK [27, 34] the Taiwanese study [33] and the Italian study [36] using the same strategy achieved much lower recruitment rates (ranging from $20 \%$ to $35 \%$ ). When the method of recruitment was workplace advertisement (WA, eight studies) [20, 22-26, 28, 31], reach was hard to estimate due to lack of information, with the exception of two studies: Strijk et al. invited all employees listed in the targeted age range $(n=3756)$ and indicated that of those $27 \%$ agreed to participate [21] and Cook et al. [24] offered a financial incentive ( $\$ 25)$ for completing the baseline survey and $96 \%$ of employees aged $>50$ years completed the survey [24]. A "first come first served" strategy was reported in two studies [23, 25], three studies reported the number of people who expressed interest in taking part from unknown denominators [22, 26, 31]. When recruitment was organised through information sessions, a strategy reported in three studies [29,30,35], the proportion of targeted employees who attended was not reported, nor was the proportion who were eligible and agreed to participate.

\subsection{Studies' quality}

Included RCTs and non-randomised studies were generally of poor quality (Supplementary Table 2). The randomisation process and concealment of allocation was mostly poorly described, resulting in an unclear judgment in nearly two thirds of trials with only four out of 11 RCTs deemed at a 'low risk' of selection bias [21, 24, 28, 29]. Lack of blinding of participants, as would be expected in trials involving behaviour modification, meant that all included studies had a high risk of performance bias. Four of the 11 RCTs relied on self-reported subjective PA outcomes [22, 24, 25, 31], resulting in a high risk of ascertainment bias in these trials. Seven trials included objective measures of PA; of those, four involved less than 40 participants [23, 26, 28, 30]. An additional major concern was the risk of selection bias due to attrition given that most trials (78\%) had incomplete outcome data, and intention-to-treat analysis was done in only four RCTs [21, 24, 28, 29]. The five included studies that were not RCTs, had a high risk of bias across almost all domains.

\subsection{Effectiveness of interventions}

Table 3 summarises the effect of the interventions on each outcome, including pooled effect sizes where meta-analysis was possible, and Figure 2 presents forest plots of the standardised mean differences (SMD). Overall, no pooled outcomes showed statistically significant differences between intervention and control groups; the quality of evidence (GRADE) was low to very low for all outcomes; and heterogeneity was moderate to high for most pooled outcomes except for flexibility and strength. Three studies examined changes in PA participation. However, the definition of participation varied, with only one examined change in those meeting aerobic recommendations in pre-post design with no comparison group [34]. Three studies examined frequency [24, 25, 33] with a pooled SMD $[24,25,33]$ of 0.25 ( $95 \% \mathrm{Cl}-0.07$ to 0.56$)$ and moderate heterogeneity $\left(\mathrm{I}^{2}=53 \%, \mathrm{p}=0.19\right)$. The study that was not included in the meta-analysis also reported non-significant differences between groups [31]. Time spent in moderate-to-vigorous PA was measured by self-report in three studies [21, 22, 32] and objectively (accelerometer) in two studies [21, 29]. The SMD was computed from accelerometer and the study by Arao (self-report), all presented results for 6- 
month follow-up. The pooled SMD was $0.22(95 \% \mathrm{Cl}-0.05$ to 0.50$)$ (see Forest plot) with low heterogeneity $\left(\mathrm{I}^{2}=46 \%, \mathrm{p}=0.16\right)$. There was also no significant difference between groups in the study not included in the meta-analysis [22]. The trials by Arao et al. and Strijk et al. included an aerobic fitness $\left(\mathrm{VO}_{2}\right.$ max $)$ measure with a pooled SMD of $0.28(95 \% \mathrm{Cl}-0.22$ to 0.78$)$ and high heterogeneity $\left(\mathrm{I}^{2}=82 \%, \mathrm{p}=0.02\right)$. A significant between-group difference in step count per day was reported by Bergman et al. [29] which was equivalent to an SMD of 0.22. Bassey et al. [27] also reported step count per day, available for half the sample, but not by allocation because they found no between group differences.

Two small scale studies $(n=57)$ reported the effect of the intervention on muscle strength (i.e., plantar strength and knee flexor) with an SMD of 0.27 ( $95 \% \mathrm{Cl}$ -0.26 to 0.80$)[28,30]$. Another study included isometric knee extensor strength as an outcome, but provided no data, suggesting selective reporting [23]. Two small scale studies $(n=46)$ reported on balance (postural control [30] and functional reach [23]) with a large pooled effect size $(S M D=1.29,95 \%$ Cl: -0.56 to $3.15)$ with high heterogeneity $\left(P^{2}=81.2 \%, p=0.021\right)$. Two studies $(n=58)$ examined the effect of the intervention on flexibility in trials of tai chi [23] and Nordic walking [26] and found a moderate sized effect (0.50) without heterogeneity, but that was also statistically non-significant (95\% $\mathrm{Cl}-0.04$ to 1.05$)$. GRADE ratings of the certainty or quality of evidence for each outcome were low to very low mostly due to the high risk of bias of included studies, high heterogeneity (inconsistency), and imprecision (all pooled Cls crossed 0 and were statistically non-significant).

\section{Discussion}

To our knowledge this is the first systematic review and meta-analysis of workplace PA interventions specifically designed for older employees. Although few interventions demonstrated significant effect on one fitness domain, collectively we found no definitive evidence of effectiveness as pooled effects remained non-significant. Methodological quality was generally poor for most of the included studies. In addition, we did not identify any program that fully addressed the WHO's broader PA recommendations, which highlight the need to incorporate balance exercises ( $\geq 3$ times a week) and muscle strengthening ( $\geq 2$ times a week) along with the aerobic recommendations [39]. Only one study examined whether participants met aerobic recommendations and only two trials targeted balance or muscle strength as main outcomes. Therefore, there is a key mismatch between the aims and outcome measures of interventions designed by the public health research community and those recommended as ideal for older adults. Additionally, this review suggests that the initial level of participation (i.e., intervention reach) was generally low, which was also noted in another systematic review of workplace health promotion interventions [40].

High heterogeneity makes the pooled estimates difficult to interpret as it is unclear whether population, intervention implementation or methodological quality issues underlie the heterogeneous results across studies. For example, two cluster RCTs reported changes at 6 months in predicted maximal oxygen uptake; the Japanese study reported a significant medium effect size based on a sub-maximal stationary bike test [32] and the Dutch study [21] reported a small nonsignificant effect on the $2 \mathrm{~km}$ walking test. The difference between these two measures could explain the high heterogeneity as well as differences related to completion rate; high in the Japanese study (85\% and $93 \%)$ and low in the Dutch study (56\% and $66 \%)$ in control and intervention, respectively.

Multiple risk factor interventions incorporated screening for cardiovascular risk factors, with no focus on other age-related health problems, such as falls, which is preventable by appropriate exercise. Such screening could be carried out either through a single self-report question (e.g., history of falls) or through assessment of physiological fall risk (e.g., poor balance, impaired leg strength). Risk of falls and related injuries is an important safety issue in older workers because the consequences of falls and injuries are greater in older employees compared to their younger counterparts [6]. Further, despite emerging evidence that resistance training is as beneficial as aerobic training for the prevention and management of cardio-metabolic risks [41, 42], none of the multiple risk factor interventions explicitly included strength training to reduce CVD/metabolic risk. Strength training was promoted to employees with osteoarthritis, in accordance with clinical guidelines [28], but only one intervention specifically targeted muscle strength to generally healthy older employees [30], supporting the recent claim that strength training has been a neglected aspect of PA promotion [43]. From the mid-forties onwards, adults lose $14 \%$ to $16 \%$ of their isokinetic leg strength each decade [44], which is a greater decline than that observed in cardiovascular capacity ( 10\% per decade) [45]. Considering that employees aged 50 years and over are likely to stay at work for another decade or more, neglecting this domain is unwarranted.

The included PA programs varied substantially in terms of the PA modality, delivery methods and duration, but none stood out as a clearly superior strategy for older employees. Compared with self-managed programs carried out in participants' discretionary time, on-site supervised sessions during the workday [21, 23, $26,30]$ tended to demonstrate high retention rates (71\% to $100 \%)$ and good compliance. However, on-site PA programs were usually shorter in duration below 15 weeks. On-site pragmatic approaches such as treadmill workstations, short breaks for balance and strength training or web-based interventions, can be easily integrated into the workday. However, the effectiveness of treadmill workstations was disappointing [29], and the evidence for other approaches was inconsistent $[22,24,30]$. These interventions should be further tested by high-quality replication studies before translational research can be conducted.

The most alarming finding is the poor quality of the RCTs we identified, with the exception of the study by Bergman et al. [29]. Study quality could be improved by appropriate randomisation, intention to treat analysis, and the use of both objective and subjective measures of PA. For example, most multiple risk factor interventions included objective measures of CVD risks (i.e., blood tests or anthropometrics), but failed to use objective fitness tests or activity trackers. Further, to improve the directness of evidence, the selection of outcome measures should better reflect the fitness dimension(s) that the proposed PA is likely to affect, such as measuring balance and strength outcomes in interventions involving yoga or tai-chi or aerobic fitness in Nordic walking interventions.

Research demonstrates increases in leisure-time PA after transition to retirement compared to during full employment [46, 47]. However, a systematic review has found disparities by socioeconomic status (SES); employees with low SES tend to be less active after retirement whereas those with high SES tend to be more active after retirement [47]. Focus groups with older retirees revealed that retirees from lower SES appear to place lower value on the importance of leisure-time PA [48]. Therefore, improving PA whilst in the workforce may be of even greater importance to older people with low SES. In this review we identified three studies that specifically targeted low paid employees in manual occupations (i.e., factory employees) in Japan and the UK [27, 32, 34]. Only the study from Japan, which included social and environmental support in addition to behavioural counselling, demonstrated significant positive effects. 
However, this study was a non-randomised study with a high risk of bias for almost all domains. Further work is therefore needed to ascertain what types of interventions can most effectively improve PA outcomes in older employees with low SES.

\subsection{Strengths and limitations}

This review has applied guideline-informed, rigorous methods to synthesise and evaluate current evidence around workplace PA interventions for older people. Compared with the 2016 systematic review by Poscia and colleagues [12], we have expanded upon the list of workplace health promotion interventions delivered to older employees by 11 studies [25-32, 34-36] by carrying out a more sensitive and comprehensive literature search. However, some limitations need to be acknowledged: first, we limited our search to electronic databases which can result in missing unpublished workplace interventions. Second, pooling effect sizes that were not expressed in similar units (e.g., kcal to minutes of at least moderate-intensity PA) may have artificially increased the heterogeneity of the effects.

\section{Conclusion}

This review highlights the need for high-quality RCTs of workplace interventions that address the broader PA recommendations for older employees. Interventions should aim to improve strength, balance and flexibility in addition to aerobic fitness. Multi-risk factor interventions need to screen for falls and injury risk that are particularly pertinent to older adults in addition to the usual focus on cardiovascular disease.

\section{List Of Abbreviations}

CVD - Cardiovascular Disease

PA - Physical activity

SMD - Standardised Mean Differences

\section{Declarations}

\section{Ethics approval and consent to participation}

Not applicable for systematic review

\section{Availability of Data and Materials}

Not applicable

\section{Competing interests}

No competing interests to declare.

\section{Funding}

There was no funding for this research.

\section{Authors' contributions}

All authors (DM, FS, JS, AT, SM, KG, DD) participated in the design, writing, interpretation of results and gave final approval of the manuscript. DM conceptualised the research and drafted the first manuscript. DM and JS conducted the systematic search and selection. FS and DD conducted the quality assessment. AT and DM conduced meta-analysis. DM and SM conducted the data extraction to tables.

\section{Consent to publication}

Not applicable

\section{Acknowledgments}

Not applicable

\section{References}

1. Christensen K, Doblhammer G, Rau R, Vaupel JW. Ageing populations: The challenges ahead. Lancet. 2009;374(9696):1196-208.

2. Sao Jose JM, Timonen V, Amado CA, Santos SP. A critique of the Active Ageing Index. J Aging Stud. 2017;40:49-56.

3. Madero-Cabib I, Kaeser L. How voluntary is the active ageing life? A life-course study on the determinants of extending careers. European $\mathrm{J}$ Ageing. 2016;13(1):25-37.

4. FitzGerald D, Reid A, O’Neill D. Promoting Workability for our ageing population. In: Parry E, McCarthy J, editors. The Palgrave handbook of age diversity and work. London: Palgrave Macmillan; 2017. p. 133-67. 
5. Chan EA, Tan V, Koh G. Ageing and fitness to work. Occup Med. 2000;50(7):483-91.

6. Crawford JO, Graveling RA, Cowie HA, Dixon K. The health safety and health promotion needs of older workers. Occup Med. 2010;60(3):184-92.

7. DiPietro L. Physical activity, fitness, and aging. In: Bouchard C, Blair SN, Haskell W, editors. Physical Activity and Health. Champaign: Human Kinetics 2012. p. 304-16.

8. Fiatarone-Singh MA. Exercise comes of age: rationale and recommendations for a geriatric exercise prescription. J Gerontol. 2002;57A(5):M262-M82.

9. Wojtek J, Chodzko-Zajko W, Proctor DN, Fiatarone Singh MA, C.T. M, C.R. N, et al. Exercise and physical activity for older adults: Position Stand. Med Sci Sports Exerc. 2009;41(7):1510-30.

10. Dishman RK, Oldenburg B, O'Neal H, Shephard RJ. Worksite physical activity interventions. Am J Prev Med. 1998;15(4):344-61.

11. Aalbers T, Qin L, Baars MA, de Lange A, Kessels RP, Olde Rikkert MG. Changing behavioral lifestyle risk factors related to cognitive decline in later life using a self-motivated eHealth intervention in Dutch adults. J Med Internet Res. 2016;18(6):e171.

12. Poscia A, Moscato U, La Milia DI, Milovanovic S, Stojanovic J, Borghini A, et al. Workplace health promotion for older workers: a systematic literature review. BMC Health Serv Res. 2016;16 Suppl 5:329.

13. Nelson ME, Rejeski WJ, Blair SN, Duncan PW, Judge JO, King AC, et al. Physical activity and public health in older adults: recommendation from the American College of Sports Medicine and the American Heart Association. Med Sci Sports Exerc. 2007;39(8):1435-45.

14. US Department of Health and Human Services. 2018 Physical Activity Guidelines Advisory Committee Scientific Report. In: Services DoHH, editor. Washington2018.

15. Higgins J, Geen S, (editors). Cochrane Handbook for Systematic Reviews of Interventions. The Cochrane Collaboration, 2011. Available from: http://handbook.cochrane.org.

16. Shamseer L, Moher D, Clarke M, Ghersi D, Liberati A, Petticrew M, et al. Preferred reporting items for systematic review and meta-analysis protocols (PRISMA-P) 2015 statement. Syst Rev. 2015;4(1):1.

17. Cohen J. Statistical Power Analysis for the Behavioral Sciences. 2nd ed. Hillsdale, NJ: Lawrence Erlbaum Associates 1988.

18. Balshema H, Helfanda M, Schunemann HJ, Oxmand AD, Kunz R, Brozek J, et al. GRADE guidelines: 3. Rating the quality of evidence. J Clin Epidemiol. 2011;64:401-6.

19. Murad MH, Mustafa RA, Schunemann HJ, Sultan S, Santesso N. Rating the certainty in evidence in the absence of a single estimate of effect. Evid Based Med. 2017;22(3):85-7.

20. Strijk JE, Proper KI, van der Beek AJ, van Mechelen W. A process evaluation of a worksite vitality intervention among ageing hospital workers. Int J Behav Nutr Phys Act. 2011;8:58.

21. Strijk JE, Proper KI, van der Beek AJ, van Mechelen W. A worksite vitality intervention to improve older workers' lifestyle and vitality-related outcomes: results of a randomised controlled trial. J Epidemiol Community Health. 2012;66(11):1071-8.

22. Hughes SL, Seymour RB, Campbell RT, Shaw JW, Fabiyi C, Sokas R. Comparison of two health-promotion programs for older workers. Am J Public Health. 2011;101(5):883-90.

23. Palumbo MV, Wu G, Shaner-McRae H, Rambur B, Mclntosh B. Tai Chi for older nurses: a workplace wellness pilot study. Appl Nurs Res. 2012;25(1):54-9.

24. Cook RF, Hersch RK, Schlossberg D, Leaf SL. A Web-based health promotion program for older workers: randomized controlled trial. J Med Internet Res. 2015;17(3):e82.

25. Low V, Gebhart B, Reich C. Effects of a worksite program to improve the cardiovascular health of female health care workers. J Cardiopulm Rehabil Prev. 2015;35(5):342-7.

26. Kocur P, Pospieszna B, Choszczewski D, Michalowski L, Wiernicka M, Lewandowski J. The effects of Nordic Walking training on selected upper-body muscle groups in female-office workers: A randomized trial. Work. 2017;56(2):277-83.

27. Bassey EJ, Patrick JM, Irving JM, Blecher A, Fentem PH. An unsupervised "aerobics" physical training programme in middle-aged factory workers: feasibility, validation and response. Eur J Appl Physiol. 1983;52(1):120-5.

28. Chopp-Hurley JN, Brenneman EC, Wiebenga EG, Bulbrook B, Keir PJ, Maly MR. Randomized controlled trial investigating the role of exercise in the workplace to improve work ability, performance, and patient-reported symptoms among older workers with osteoarthritis. $\mathrm{J}$ Occup Environ Med. 2017;59(6):550-6.

29. Bergman F, Wahlstrom V, Stomby A, Otten J, Lanthen E, Renklint R, et al. Treadmill workstations in office workers who are overweight or obese: a randomised controlled trial. Lancet Public Health. 2018;3(11):e523-e35.

30. Granacher U, Wick C, Rueck N, Esposito C, Roth R, Zahner L. Promoting balance and strength in the middle-aged workforce. Int J Sports Med. 2011;32(1):35-44.

31. Sharpe PA, Connell CM. Exercise beliefs and behaviors among older employees: a health promotion trial. Gerontologist. 1992;32(4):444-9.

32. Arao T, Oida Y, Maruyama C, Mutou T, Sawada S, Matsuzuki H, et al. Impact of lifestyle intervention on physical activity and diet of Japanese workers. Prev Med. 2007;45(2-3):146-52.

33. Chen MM, Tsai AC, Wang JY. The effectiveness and barriers of implementing a workplace health promotion program to improve metabolic disorders in older workers in Taiwan. Global Health Promot. 2016;23(2):6-14.

34. Abbas SZ, Pollard TM, Wynn P, Learmonth A, Joyce K, Bambra C. The effectiveness of using the workplace to identify and address modifiable health risk factors in deprived populations. Occup Environ Med. 2015;72(9):664-9. 
35. Naug HL, Colson NJ, Kundur A, Santha Kumar A, Tucakovic L, Roberts M, et al. Occupational health and metabolic risk factors: A pilot intervention for transport workers. Int J Occup Med Environ Health. 2016;29(4):573-84.

36. Scapellato ML, Comiati V, Buja A, Buttignol G, Valentini R, Burati V, et al. Combined Before-and-After Workplace Intervention to Promote Healthy Lifestyles in Healthcare Workers (STI-VI Study): Short-Term Assessment. Int J Environ Res Public Health. 2018;15(9):19.

37. Youkhana S, Dean C, Wolff M, Sherrington C, Tiedemann A. Yoga-based exercise improves balance and mobility in people aged 60 years and over: a systematic review and meta-analysis. Age \& Ageing. 2016;45(1):20-9.

38. Wayne PM, Kaptchuk, T. J. Challenges inherent to t'ai chi research: part I-t'ai chi as a complex multicomponent intervention. J Altern Complement Med. 2008;14(1):95-102.

39. World Health Organization. Physical activity and older adults 2019 [Available from: https://www.who.int/dietphysicalactivity/factsheet_olderadults/en/.

40. Robroek SJ, van Lenthe FJ, van Empelen P, Burdorf A. Determinants of participation in worksite health promotion programmes: a systematic review. Int $J$ Behav Nutr Phys Act. 2009;6:26.

41. Pollock ML, Franklin BA, Balady GJ, Bernard L. Chaitman, Fleg JL, Fletcher B, et al. Resistance exercise in individuals with and without cardiovascular disease benefits, rationale, safety, and prescription: An advisory from the Committee on Exercise, Rehabilitation, and Prevention, Council on Clinical Cardiology, American Heart Association. Circulation. 2000;101:828-33.

42. Grøntved A, Pan A, Mekary RA, Stampfer M, Willett WC, Manson JE, et al. Muscle-strengthening and conditioning activities and risk of Type 2 Diabetes: A prospective study in two cohorts of US women. PLoS Med. 2014;11(1):e1001587.

43. Steele J, Fisher J, Skivington M, Dunn C, Arnold J, Tew G, et al. A higher effort-based paradigm in physical activity and exercise for public health: making the case for a greater emphasis on resistance training. BMC Public Health. 2017;17:300.

44. Hughes VA, Frontera WR, Wood M, Evans WJ, Dallal GE, Roubenoff R, et al. Longitudinal muscle strength changes in older adults: influence of muscle mass, physical activity, and health. J Gerontol A Biol Sci Med Sci. 2001;56(5):B210-B7.

45. Hollenberg M, Yang J, Haight TJ, Tager IB. Longitudinal changes in aerobic capacity: Implications for concepts of aging. J Gerontol. 2006;61A(8):851-8.

46. Ding D, Grunseit AC, Chau JY, Vo K, Byles JE, Bauman A. Retirement-A transition to a healthier lifestyle? Am J Prev Med. 2016.

47. Barnet I, van Sluijs EMF, Ogilvie D. Physical activity and transitioning to retirement: A Systematic Review. Am J Prev Med. 2012;43(3):329 -36.

48. Barnet I, Guell C, Ogilvie D. The experience of physical activity and the transition to retirement: a systematic review and integrative synthesis of qualitative and quantitative evidence. Int J Behav Nutr Phys Act. 2012;9:97.

\section{Tables}

Table 1: Characteristics of the studies that met the inclusion criteria in worksite older employees' physical activity (PA) interventions arranged by design and year 


\begin{tabular}{|c|c|c|c|c|c|c|}
\hline & \multirow{2}{*}{$\begin{array}{l}\text { Design } \\
\text { Sample }\end{array}$} & \multirow[t]{2}{*}{ Population } & \multirow{2}{*}{\multicolumn{2}{|c|}{ Intervention }} & \multicolumn{2}{|r|}{ Physical activity outcomes } \\
\hline & & & & & & \\
\hline $\begin{array}{l}\text { Bassey et } \\
\text { al. } 1983 \\
{[27]}\end{array}$ & $\begin{array}{l}\text { RCT } \\
\mathrm{N}=108\end{array}$ & $\begin{array}{l}\text { UK, factory floor } \\
\text { workers (blue collar) } \\
\text { from light industrial } \\
\text { company, } \\
\text { age 55-60, } \\
51 \% \text { males }\end{array}$ & $\begin{array}{l}12 \\
\text { weeks }\end{array}$ & $\begin{array}{l}\text { PA focus; prescribed aerobic } \\
\text { (walking) program with a goal to } \\
\text { increase cardiorespiratory fitness }\end{array}$ & No intervention & $\begin{array}{l}\text { 1) Physical condition - heart rate (HR) at } \\
\text { walking } 4.8 \mathrm{~km} / \mathrm{hr} \\
\text { 2) Sustained } \mathrm{HR}_{4.8 \mathrm{kmh}^{-1}} \text { for at least } 7 \\
\text { minutes } \\
\text { 3) Daily total minutes walked } \\
\text { at } \mathrm{HR}_{4.8 \mathrm{kmh}}{ }^{-1} \\
\text { 4) Step count }\end{array}$ \\
\hline $\begin{array}{l}\text { Sharpe et } \\
\text { al. } 1992 \\
{[31]}\end{array}$ & $\begin{array}{l}\text { Cluster } \\
\text { RCT } \\
\mathrm{N}=250\end{array}$ & $\begin{array}{l}\text { USA, employees from } \\
\text { 'support and } \\
\text { academic staff" at } \\
\text { the University of } \\
\text { Michigan, } \\
\text { age 50-69, } \\
53 \% \text { males }\end{array}$ & $\begin{array}{l}12 \\
\text { months }\end{array}$ & $\begin{array}{l}\text { Multiple risk factor program; } \\
\text { after health risk screening a face- } \\
\text { to-face meeting with health } \\
\text { promoter; optional: walking } \\
\text { groups at work/ or use the site } \\
\text { exercise facilities. }\end{array}$ & $\begin{array}{l}\text { Health screening, } \\
\text { but no exposure to } \\
\text { health promotion } \\
\text { program }\end{array}$ & $\begin{array}{l}\text { 1) Self report frequency item with a 5-point } \\
\text { response format -which were not explained } \\
\text { or referenced. } \\
\text { 2) Self-reported action taken to improve } \\
\text { fitness in the past year } \\
\text { 3) Precursors of exercise behaviours (self- } \\
\text { efficacy to exercise } 3 \text { times a week and } \\
\text { intention to exercise vigorously }\end{array}$ \\
\hline
\end{tabular}

\begin{tabular}{|c|c|c|c|c|c|}
\hline $\begin{array}{l}\text { Hughes } \\
\text { et al. } \\
2011 \\
{[22]}\end{array}$ & $\begin{array}{l}\text { RCT } \\
(3 \\
\text { arms) } \\
\mathrm{N}=423\end{array}$ & $\begin{array}{l}\text { USA, older employees } \\
\text { from "support and } \\
\text { academic" staff at the } \\
\text { University of Illinois, } \\
\text { Chicago } \\
\text { Age } \geq 55 \text { years } \\
18 \% \text { males }\end{array}$ & $\begin{array}{l}12 \\
\text { months }\end{array}$ & $\begin{array}{l}\text { Multiple risk factors; } \\
\text { 1) Enhance Wellness one-on-one } \\
\text { coaching program (COACH) } \\
\text { 2) a web-based health promotion } \\
\text { program (RealAge) }\end{array}$ & $\begin{array}{l}\text { Printed health } \\
\text { promotion materials } \\
\text { programs and } \\
\text { services offered by } \\
\text { university or by } \\
\text { community } \\
\text { organisations }\end{array}$ \\
\hline
\end{tabular}

1) Self -report minutes of moderateintensity and minutes in vigorous-intensity Using the Behavioral Risk Factor Surveillance System (typical week -7 questions)

2) The Rapid Assessment of Physical Activity (RAPA) for meeting recommendation based on 9 items (aerobic muscle training and flexibility, response: yes $=1$, no $=0$ combined to total score

\begin{tabular}{|c|c|c|c|c|c|c|}
\hline $\begin{array}{l}\text { Strijk et al. } \\
2011 \text { [20] \& } \\
2012[21]\end{array}$ & $\begin{array}{l}\text { RCT } \\
\mathrm{N}=730\end{array}$ & $\begin{array}{l}\text { Netherlands, workers } \\
\text { from two academic } \\
\text { hospitals } \\
\text { Age } \geq 45 \text { years } \\
\text { Mean age } 52.3 \pm 4.9 \\
25 \% \text { males }\end{array}$ & $\begin{array}{l}6 \\
\text { months }\end{array}$ & $\begin{array}{l}\text { Dual risk factors Diet and PA: } \\
\text { Vital@work } \\
\text { Yoga session } 60 \text { minutes and } \\
\text { workout classes } 30 \text { minutes plus } \\
\text { home based aerobic session }\end{array}$ & $\begin{array}{l}\text { General healthy } \\
\text { lifestyle written } \\
\text { information - diet, } \\
\text { physical activity and } \\
\text { relaxation }\end{array}$ & $\begin{array}{l}\text { 1) The frequency, duration and intensity of } \\
\text { participation in commuting, household, } \\
\text { occupation and leisure-time PA using the } \\
\text { SQUASH }{ }^{a} \text { questionnaire: } \\
\text { 2) Minutes spent on sport-from SQUASH } \\
\text { 3) Accelerometer minutes in MVPA on sub- } \\
\text { sample (GTM1 Actigraph) } \\
\text { 4) Aerobic capacity (VO2max) was } \\
\text { estimated using the UKK }{ }^{\text {b }} 2 \mathrm{~km} \text { walk test. }\end{array}$ \\
\hline
\end{tabular}

\begin{tabular}{|c|c|c|c|c|c|c|}
\hline $\begin{array}{l}\text { Palumbo et } \\
\text { al. } 2012 \\
\text { [23] }\end{array}$ & $\begin{array}{l}\mathrm{RCT} \\
\mathrm{N}=14\end{array}$ & $\begin{array}{l}\text { USA, female nurses } \\
\text { from an academic } \\
\text { medical center in } \\
\text { Vermont } \\
\text { Age } \geq 49 \text { years } \\
0 \% \text { males }\end{array}$ & $\begin{array}{l}15 \\
\text { weeks }\end{array}$ & $\begin{array}{l}\text { PA focus: Once a week Tai-chi } \\
\text { guided classes at work for } 45 \\
\text { minutes and unguided home- } \\
\text { based practice } 10 \text {-mins } 4 \text { times a } \\
\text { week }\end{array}$ & No intervention & $\begin{array}{l}\text { 1) Flexibility of trunk "Sit-and-Reach" test } \\
\text { 2) Strength: isometric knee extensor test } \\
\text { with dynamometer } \\
\text { 3) Balance-Functional Reach test (cm) }\end{array}$ \\
\hline $\begin{array}{l}\text { Cook et al. } \\
2015 \\
{[24]}\end{array}$ & $\begin{array}{l}\mathrm{RCT} \\
\mathrm{N}=278\end{array}$ & $\begin{array}{l}\text { USA, IT employees } \\
\text { from two major } \\
\text { global IT companies } \\
\text { in California and } \\
\text { Boston } \\
\text { Age - } 50 \text { to } 68 \text { years } \\
67 \% \text { males }\end{array}$ & $\begin{array}{l}12 \\
\text { weeks }\end{array}$ & $\begin{array}{l}\text { Multiple risk factors web-based } \\
\text { educational program } \\
\text { "HealthyPast50" with no human } \\
\text { contact. }\end{array}$ & $\begin{array}{l}\text { No intervention } \\
\text { Wait-listed }\end{array}$ & $\begin{array}{l}\text { 1) Exercise habits: based on Godin LTPA } \\
\text { score measuring frequency per week } \\
\text { exercising at } 3 \text { levels (mild, moderate } \\
\text { strenuous) and the number multiplied by } \\
\text { intensity factor -reported frequency at each } \\
\text { level and in total } \\
\text { 2) Exercise self-efficacy score (8-items) 4- } \\
\text { point scale } \\
\text { 3) Exercise intention }\end{array}$ \\
\hline
\end{tabular}




\begin{tabular}{|c|c|c|c|c|c|c|}
\hline & Design & Population & & Intervention & Compar & Physical activity outcomes \\
\hline $\begin{array}{l}\text { Low et al. } \\
2015 \\
{[25]}\end{array}$ & $\begin{array}{l}\text { RCT } \\
\mathrm{N}=62\end{array}$ & $\begin{array}{l}\text { USA, female } \\
\text { employees of a busy } \\
\text { community hospital, } \\
\text { North Carolina } 40-65 \\
\text { years old; } \\
\text { mean age } 52 \pm 6.3 \text {. }\end{array}$ & $\begin{array}{l}6 \\
\text { months }\end{array}$ & $\begin{array}{l}\text { Multiple risk factors program to } \\
\text { reduce CVD }{ }^{\mathrm{C}} \text { risk as in control, } \\
\text { plus weekly motivational sessions } \\
\text { by mail or telephone for goal } \\
\text { setting }\end{array}$ & $\begin{array}{l}\text { Risk reduction } \\
\text { educational classes; } \\
\text { Free access to gym } \\
\text { on site and walking } \\
\text { group }\end{array}$ & $\begin{array}{l}\text { 1) Frequency - days per week of exercising } \\
\text { 2) Minutes per session of exercising } \\
\text { 3) Level of intensity: no exercise, leisurely, } \\
\text { moderate, or vigorous exercise (reported as } \\
\text { \%) } \\
\text { 4) Readiness to change exercise }\end{array}$ \\
\hline
\end{tabular}

\begin{tabular}{|c|c|c|c|c|c|c|}
\hline $\begin{array}{l}\text { Granacher } \\
\text { et al. } 2011 \\
\text { [30] }\end{array}$ & $\begin{array}{l}\text { Cluster } \\
\text { RCT } \\
\mathrm{N}=32\end{array}$ & $\begin{array}{l}\text { Switzerland, } \\
\text { sedentary office } \\
\text { workers from two } \\
\text { large companies in } \\
\text { Basel, } \\
\text { Age } \geq 50 \\
37 \% \text { males }\end{array}$ & 8 weeks & $\begin{array}{l}\text { PA focus; progressive balance } \\
\text { and strength training at the office } \\
\text { using exercise charts to perform } \\
3 \text { times a day; each session lasts } \\
8 \text { minutes }\end{array}$ & No intervention & $\begin{array}{l}\text { 1) Balance (static) postural control using } \\
\text { balance platform, standing on one leg } 30 \\
\text { seconds eyes open-displacement of COP } \mathrm{d} \\
\text { 2) Gait variability and speed on special } \\
\text { treadmill } \\
\text { 3) Force jumping height measured on a } \\
\text { force platform } \\
\text { 4) Maximal isometric \& isokinetic torque } \\
\text { (60 / and rate of torque development } \\
\text { (RTD) of the plantar flexor using force } \\
\text { platform }\end{array}$ \\
\hline
\end{tabular}

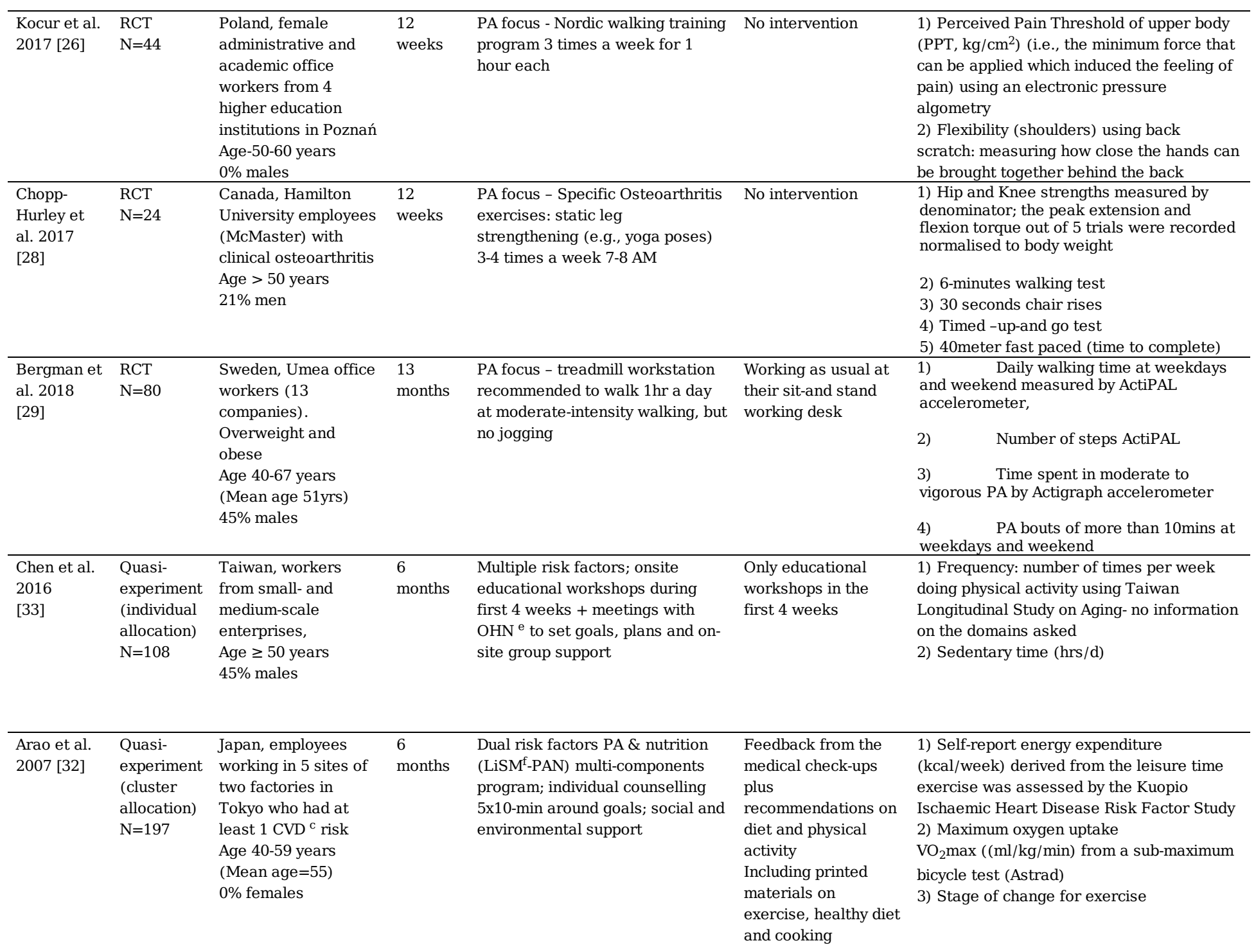




\begin{tabular}{|c|c|c|c|c|c|c|}
\hline & $\begin{array}{l}\text { Design } \\
\text { Sample }\end{array}$ & Population & & Intervention & & Physical activity outcomes \\
\hline $\begin{array}{l}\text { Abbas et al. } \\
2015 \text { [34] }\end{array}$ & $\begin{array}{l}\text { Pre-post } \\
\mathrm{N}=665\end{array}$ & $\begin{array}{l}\text { UK, low-paid local } \\
\text { government } \\
\text { employees from } \\
\text { socially and } \\
\text { economically } \\
\text { deprived areas in NE } \\
\text { England, } \\
\text { Age } \geq 40 \text { years mean } \\
\text { age } 50.5 \pm 6.4 \\
37 \% \text { males }\end{array}$ & $\begin{array}{l}9 \\
\text { months }\end{array}$ & $\begin{array}{l}\text { Multiple risk factors health } \\
\text { screening staging risk level and } \\
\text { referrals to exercise, weight } \\
\text { management, smoking cessation, } \\
\text { promotion of mental health and } \\
\text { alcohol reduction }\end{array}$ & ---- & $\begin{array}{l}\text { 1) Participation in aerobic exercise } \\
\text { dichotomised to not meeting } \\
\text { recommendation (less than } 5 \text { times a week } \\
\text { of less than 30-minutes session) referred to } \\
\text { exercise } \\
\text { 2) Question on doing exercise outside work } \\
\text { (report on \% before and after) }\end{array}$ \\
\hline $\begin{array}{l}\text { Naug et al. } \\
2016 \text { [35] }\end{array}$ & $\begin{array}{l}\text { Pre-post } \\
\text { Pilot trial } \\
\mathrm{N}=33\end{array}$ & $\begin{array}{l}\text { Australia, bus drivers } \\
\text { from two depots of } \\
\text { South east } \\
\text { Queensland } \\
\text { Age: } 50-68 \text { years } \\
64 \% \text { males }\end{array}$ & 6 weeks & $\begin{array}{l}\text { Dual risk factors diet and PA. } \\
\text { Group educational sessions; harm } \\
\text { of sitting, healthy eating \& } \\
\text { exercise; PA - pedometer to track } \\
\text { steps }\end{array}$ & ----- & $\begin{array}{l}\text { 1) Exercise levels - no report on } \\
\text { questionnaire type; researcher driven } \\
\text { classification: a) none (no exercise) } \\
\text { b) moderate level (e.g. 30-40min walking } \\
\text { twice a week or tennis once a week) } \\
\text { c) intense (e.g., gym } 4-7 \text { times a week or } \\
\text { cycling } 5 \text { days/week) } \\
\text { 2) Sedentary behaviour (hrs/week) }\end{array}$ \\
\hline $\begin{array}{l}\text { Scapellato } \\
\text { et al. } 2018 \\
{[36]}\end{array}$ & $\begin{array}{l}\text { Pre-post } \\
\mathrm{N}=167\end{array}$ & $\begin{array}{l}\text { Italy, Padua } \\
\text { healthcare worker at } \\
\text { risk of CVD } \\
\text { Mean age } 50 \pm 7.3 \\
31.7 \% \text { males }\end{array}$ & $\begin{array}{l}6 \\
\text { months }\end{array}$ & $\begin{array}{l}\text { Dual risk factors diet and PA, } \\
\text { brochure on exercise and } \\
\text { motivational counselling on site at } \\
\text { baseline and mid-term by phone }\end{array}$ & ----- & $\begin{array}{l}\text { 1) } \text { PA MET }^{\mathrm{h}} \text { based on a 4-day diary about } \\
\text { the type of activity, frequency (day per } \\
\text { week) and duration (minutes) }\end{array}$ \\
\hline
\end{tabular}

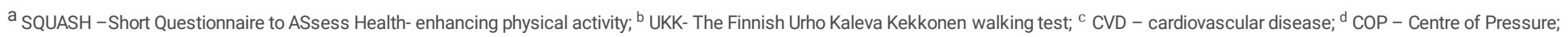
${ }^{\mathrm{e}} \mathrm{OHN}$ - Occupational health nurse; ${ }^{\mathrm{f}} \mathrm{LiSM}$ - Lifestyle Modification; ${ }^{\mathrm{g}} \mathrm{GHQ}$ - General Health Questionnaire; ${ }^{\mathrm{h}}$ MET- Metabolic Equivalent

Table 2: Summary of the characteristics of workplace physical activity interventions delivered to older employees 


\begin{tabular}{|c|c|c|c|c|c|c|c|c|c|c|c|c|c|c|c|c|}
\hline & \multicolumn{6}{|c|}{ Multiple risk factor interventions } & \multicolumn{4}{|c|}{$\begin{array}{c}\text { Physical activity \& } \\
\text { nutrition }\end{array}$} & \multicolumn{6}{|c|}{ Physical activity only } \\
\hline Intervention & $\begin{array}{l}\text { Abbas } \\
2015\end{array}$ & Chen2016 & $\begin{array}{l}\text { Cook } \\
2015\end{array}$ & \begin{tabular}{|l|} 
Hughes \\
2011
\end{tabular} & \begin{tabular}{|l|} 
Low \\
2015
\end{tabular} & \begin{tabular}{|l|} 
Sharpe \\
1992
\end{tabular} & $\begin{array}{l}\text { Arao } \\
2007\end{array}$ & \begin{tabular}{|l|} 
Strijk \\
2011 \\
/2012
\end{tabular} & $\begin{array}{l}\text { Naug } \\
2016\end{array}$ & \begin{tabular}{|l|} 
Scape- \\
llato \\
2018 \\
\end{tabular} & $\begin{array}{l}\text { Bassey } \\
1983\end{array}$ & $\begin{array}{l}\text { Grana- } \\
\text { cher } \\
2011\end{array}$ & \begin{tabular}{|l|} 
Palu- \\
mbo \\
2012 \\
\end{tabular} & \begin{tabular}{|l|} 
Kocur \\
2017 \\
\end{tabular} & $\begin{array}{l}\text { ChopHurley } \\
2017\end{array}$ & $\begin{array}{l}\text { Ber! } \\
\text { man } \\
201:\end{array}$ \\
\hline $\begin{array}{l}\text { Aerobic } \\
\text { workout, } \\
\text { walking, } \\
\text { steps } \\
\text { accumulation }\end{array}$ & & & & $\mathrm{X}$ & $\mathrm{X}$ & $\mathrm{X}$ & $\mathrm{X}$ & $\mathrm{X}$ & $\mathrm{X}$ & & $\mathrm{X}$ & $\mathrm{X}$ & & & & $\bar{X}$ \\
\hline $\begin{array}{l}\text { Nordic } \\
\text { walking }\end{array}$ & & & & & & & & & & & & & & $\bar{X}$ & & \\
\hline $\begin{array}{l}\text { Balance } \\
\text { exercise }\end{array}$ & & & & & & & & & & & & $\mathrm{X}$ & & & & \\
\hline Muscle strength & & & & & & & & & & & & $\bar{X}$ & & & $\bar{X}$ & \\
\hline Flexibility & & & & & & & & & & & & & & & & \\
\hline $\begin{array}{l}\text { Multi- } \\
\text { dimensional }\end{array}$ & & & & & & & & $\begin{array}{c}\mathrm{X}- \\
\text { yoga }\end{array}$ & & & & & $\begin{array}{c}\mathrm{X} \\
\text { tai } \\
\text { chi }\end{array}$ & & & \\
\hline $\begin{array}{l}\text { Generic } \\
\text { description } \\
\text { 'exercise } \\
\text { goals', } \\
\text { referral to } \\
\text { class }\end{array}$ & $\bar{X}$ & $\mathrm{X}$ & $\mathrm{X}$ & $\mathrm{X}$ & $\mathrm{X}$ & $\mathrm{X}$ & & & & $\mathrm{X}$ & & & $\mathrm{X}$ & & & \\
\hline Delivery mode ${ }^{a}$ & SM & IC & SM & $\mathrm{IC} / \mathrm{SM}$ & OS & $\mathrm{IC}$ & IC & OS & SM & $\mathrm{IC}$ & SM & OS & OS & OS & OS & $\mathrm{Os}$ \\
\hline Duration ${ }^{b}$ & $\mathrm{M}$ & $\mathrm{M}$ & $\mathrm{S}$ & $\mathrm{L}$ & $\mathrm{M}$ & $\mathrm{L}$ & $\mathrm{M}$ & $\mathrm{M}$ & S & $\mathrm{M}$ & $\mathrm{S}$ & $\mathrm{S}$ & $\mathrm{S}$ & $\mathrm{S}$ & S & $\bar{L}$ \\
\hline $\begin{array}{l}\text { Recruitment } \\
\text { method }^{c}\end{array}$ & TS & TS & WA & WA & WA & WA & TS & WA & $\mathrm{I}$ & TS & TS & $\mathrm{I}$ & WA & WA & WA & $\overline{\mathrm{I}}$ \\
\hline $\begin{array}{l}\text { Process } \\
\text { outcomes d }\end{array}$ & \begin{tabular}{l|}
$\mathrm{R}$ \\
$64 \%$ \\
C no \\
report \\
$\mathrm{F}$
\end{tabular} & $\begin{array}{l}\text { R } 96 \% \\
\text { Q }\end{array}$ & $\begin{array}{l}\mathrm{R} \\
80 \% \\
\mathrm{C} \\
72 \%\end{array}$ & $\begin{array}{l}R_{\text {arm1 } 191 \%} \\
R_{\text {arm2 }} 51 \% \\
C_{\text {arm1 } 197 \%} \\
C_{\text {arm2 }} 57 \% \\
F\end{array}$ & \begin{tabular}{|l|}
$\mathrm{R}$ \\
$28 \%$ \\
$\mathrm{C}$ \\
Means \\
ses/wk \\
very \\
poor
\end{tabular} & \begin{tabular}{|l|}
$\mathrm{R}$ \\
$63 \%$ \\
$\mathrm{C}$ \\
$73 \%$ \\
\end{tabular} & $\begin{array}{l}\mathrm{R} \\
95 \% \\
\mathrm{C} \\
55 \%\end{array}$ & \begin{tabular}{|l|}
$\mathrm{R}$ \\
$80 \%$ \\
\\
$\mathrm{C}$ \\
$73 \%$ \\
\end{tabular} & $\begin{array}{l}\mathrm{R} \\
64 \% \\
\text { C- no } \\
\text { report } \\
\mathrm{Q}\end{array}$ & \begin{tabular}{|l|}
$\mathrm{R}$ \\
$53 \%$ \\
$\mathrm{C}$-no \\
report \\
F
\end{tabular} & $\begin{array}{l}\text { R } \\
54 \% \\
\mathrm{C} \\
33 \%\end{array}$ & $\begin{array}{l}\text { R } \\
100 \% \\
C \\
99 \%\end{array}$ & \begin{tabular}{|l|l}
$\mathrm{R}$ \\
$71 \%$ \\
$\mathrm{C}$ \\
$82 \%$ \\
$\mathrm{~F}$
\end{tabular} & \begin{tabular}{|l|}
$\mathrm{R}$ \\
$91 \%$ \\
$\mathrm{C}-$ no \\
report
\end{tabular} & $\begin{array}{l}\mathrm{R} \\
75 \% \\
\text { C Means } \\
\text { ses/wk } 1.2 \\
\text { (poor) }\end{array}$ & $\begin{array}{l}\mathrm{R} \\
85 \% \\
\mathrm{C}-\mathrm{r} \\
\text { repc }\end{array}$ \\
\hline PA outcomes ${ }^{\mathrm{e}}$ & NA & + & + & - & - & - & + & NA & - & NA & + & $+t_{1}$ & + & $+_{1}$ & $+_{1}$ & + \\
\hline $\begin{array}{l}\text { a Delivery mode: } \\
\text { b }{ }^{a} \text { Duration: S -sho } \\
{ }^{c} \text { Recruitment: T- } \\
d^{d} \text { Process outcom } \\
e^{\text {e }}+\text { significant b } \\
\text { "-“ = no between }\end{array}$ & $\begin{array}{l}\text { S-on site } \\
\mathrm{rt} \leq 15 \mathrm{w} \\
\text { argeted s } \\
\text { : } \mathrm{R} \text {-rete } \\
\text { tween g } \\
\text { group eff }\end{array}$ & $\begin{array}{l}\text { PA session } \\
\text { eeks, M - me } \\
\text { trategy, WA } \\
\text { ntion of inte } \\
\text { roups positi } \\
\text { ect on PA m }\end{array}$ & $\begin{array}{l}\text { s, SM - } \\
\text { edium } 6 \\
\text { - work } \\
\text { rventio } \\
\text { e effec } \\
\text { easure, }\end{array}$ & $\begin{array}{l}\text { self-manage } \\
-9 \text { months, L } \\
\text { site advertis } \\
\text { participant } \\
\text { t/s in favour } \\
\mathrm{NA}=\text { if no cc }\end{array}$ & $\begin{array}{l}\text { d program } \\
\text { - long }>9 \\
\text { ement inv } \\
\text { s, C -comp } \\
\text { of interve } \\
\text { omparison }\end{array}$ & $\begin{array}{l}\text {, IC -indi } \\
\text { months } \\
\text { iting part } \\
\text { liance \% } \\
\text { ntions, + } \\
\text { group }\end{array}$ & osig & $\begin{array}{l}\text { I -inf } \\
\text { al targ } \\
\text { cant b }\end{array}$ & $\begin{array}{l}\text { nation } \\
F \text {-fide } \\
\text { veen } g\end{array}$ & $\begin{array}{l}\text { ession } \\
\text { lity of in } \\
\text { oups p }\end{array}$ & $\begin{array}{l}\text { d volu } \\
\text { ventio } \\
\text { ive eff }\end{array}$ & $\begin{array}{l}\text { ers to } \\
\text { elivery } \\
\text { in fav }\end{array}$ & $\begin{array}{l}\text { e part } \\
\text {-qualita } \\
\text { of inter }\end{array}$ & $\begin{array}{l}\text { tive col } \\
\text { ventior }\end{array}$ & $\begin{array}{l}\text { nents } \\
\text { n one PA o }\end{array}$ & \\
\hline
\end{tabular}


Table 3 : Summary of results of PA/ fitness outcomes with GRADE rating of evidence

\begin{tabular}{|c|c|c|c|c|}
\hline $\begin{array}{l}\text { PA } \\
\text { Outcomes }\end{array}$ & $\begin{array}{l}\text { Standardised Mean Difference (SMD) / or } \\
\text { narrative summary }\end{array}$ & $\begin{array}{l}\text { Numbers } \\
\text { (studies) }\end{array}$ & $\begin{array}{l}\text { Quality of } \\
\text { evidence } \\
\text { (GRADE) }\end{array}$ & Comments \\
\hline $\begin{array}{l}\text { PA / exercise } \\
\text { participation } \\
(\%)\end{array}$ & $\begin{array}{l}\text { In the RCT by Sharpe } 52 \% \text { in the } \\
\text { Intervention and } 48 \% \text { of Control reported to } \\
\text { take action to improve fitness. In the RCT by } \\
\text { Low a significant reduction in those "not } \\
\text { exercising" (from } 33 \% \text { to } 6 \% \text { ) was reported } \\
\text { for both intervention and control. The pre- } \\
\text { post evaluation by Abbas et al reported } \\
\text { increase from } 49 \% \text { at baseline to } 78 \% \text { at } \\
\text { follow-up in those meeting aerobic } \\
\text { recommendation }\end{array}$ & $\begin{array}{l}687 \\
(3 \\
\text { studies })\end{array}$ & $\begin{array}{l}\text { Very Low } \\
>\text { OOO } \\
\text { Serious } \\
\text { methodological } \\
\text { limitations by } \\
\text { design, High risk } \\
\text { of bias, } \\
\text { indirectness due } \\
\text { to large } \\
\text { differences in } \\
\text { what } \\
\text { 'participation' } \\
\text { meant across } \\
\text { studies }\end{array}$ & $\begin{array}{l}\text { In the RCT by Low the control arm received } \\
\text { intensive intervention thus expecting } \\
\text { between-group small difference but the } \\
\text { authors did not report the change by } \\
\text { allocation suggesting selective reporting; as } \\
\text { results could have been in favour of the } \\
\text { control suggesting that additional } \\
\text { communications with participants did not } \\
\text { add value to the control condition. }\end{array}$ \\
\hline $\begin{array}{l}\text { Frequency } \\
\text { PA / exercise } \\
\text { (per week) }\end{array}$ & $\begin{array}{l}\text { SMD }=0.2595 \% \quad \text { CI: }-0.07 \text { to } 0.56 \\
\text { Heterogeneity }=54 \% p=0.114\end{array}$ & $\begin{array}{l}448 \\
\text { (3 } \\
\text { studies) }\end{array}$ & $\begin{array}{l}\text { Very Low } \\
>\text { OOO } \\
\text { Serious } \\
\text { methodological } \\
\text { limitations; } \\
\text { serious } \\
\text { indirectness; } \\
\text { inconsistency } \\
\text { with studies not } \\
\text { included }\end{array}$ & $\begin{array}{l}\text { One non- randomised trial with serious risk } \\
\text { of selection bias. All interventions were } \\
\text { multiple risk factors and were self-managed; } \\
\text { the exact nature of the exercise intervention } \\
\text { and the goals set for people were unclear } \\
\text { hence hard to attribute increase to the } \\
\text { intervention. Sharpe et al. measured } \\
\text { frequency but the extraction of SMD from } \\
\text { mixed model with interaction was not } \\
\text { possible. No significant between groups } \\
\text { differences were found. }\end{array}$ \\
\hline $\begin{array}{l}\text { Moderate-to } \\
\text { vigorous } \\
\text { physical } \\
\text { activity } \\
\text { (MVPA) }\end{array}$ & $\begin{array}{l}\text { SMD }=0.22, \quad 95 \% \text { CI: }-0.05 \text { to } 0.50 \\
\text { Heterogeneity }=46.2 \% p=0.16\end{array}$ & $\begin{array}{l}404 \\
(3 \\
\text { studies) }\end{array}$ & $\begin{array}{l}\text { Low } \\
>>00 \\
\text { The pooled } \\
\text { effect size was } \\
\text { derived from } \\
\text { accelerometer } \\
\text { data in intention } \\
\text { to treat analysis } \\
\text { (2-studies) and } \\
\text { one self-report } \\
\text { non-randomised } \\
\text { trial and } \\
\text { therefore reduce } \\
\text { overall quality }\end{array}$ & $\begin{array}{l}\text { One additional study (Hughes et al) was not } \\
\text { included due to inability to calculate SMD } \\
\text { from mixed model with interactions term. } \\
\text { The study reported no between-groups } \\
\text { significant effect. }\end{array}$ \\
\hline
\end{tabular}

Table 3 (continued)

\begin{tabular}{|c|c|c|c|c|}
\hline $\begin{array}{l}\text { PA } \\
\text { Outcomes }\end{array}$ & $\begin{array}{l}\text { Standardised Mean Difference (SMD) / or } \\
\text { narrative summary }\end{array}$ & $\begin{array}{l}\text { Number } \\
\text { (studies) }\end{array}$ & $\begin{array}{l}\text { Quality of } \\
\text { evidence } \\
\text { (GRADE) }\end{array}$ & Comments \\
\hline $\begin{array}{l}\text { Step counts } \\
\text { per day }\end{array}$ & $\begin{array}{l}\text { Bergman et al. reported significant between } \\
\text { group difference at } 13 \text { months in favour of } \\
\text { intervention } 1636 \text { (95\% CI: } 787 \text { to 2485). }\end{array}$ & $\begin{array}{l}80 \\
\text { (1 study) }\end{array}$ & $\begin{array}{l}\text { Low } \\
>>\mathrm{OO} \\
\text { Evidence derived } \\
\text { from one RCT } \\
\text { hence inability to } \\
\text { overall certainty }\end{array}$ & $\begin{array}{l}\text { The study by Bassey et al reported pre-post } \\
\text { mean increase of } 1300( \pm 600) \text { in steps } \\
\text { counts among sub-sample }(\mathrm{n}=54) \text { who } \\
\text { remained at all-time measurements, but not } \\
\text { by allocation; hence was not included in } \\
\text { meta -analysis }\end{array}$ \\
\hline $\begin{array}{l}\text { Aerobic } \\
\text { fitness } \\
\mathrm{VO}_{2} \text { max }\end{array}$ & $\begin{array}{l}\text { SMD }=0.2895 \% \mathrm{CI}:-0.22 \text { to } 0.78 \\
\text { Heterogeneity }=82 \% \mathrm{p}=0.019\end{array}$ & $\begin{array}{l}389 \\
(2 \\
\text { studies })\end{array}$ & $\begin{array}{l}\text { Low } \\
>>00 \\
\text { Serious } \\
\text { methodological } \\
\text { limitations; } \\
\text { inconsistency }\end{array}$ & $\begin{array}{l}\text { Strijik cluster RCT high loss for this } \\
\text { measure and high risk of performance } \& \\
\text { ascertainment bias; Ara is a non-RCT with } \\
\text { high risk of bias due to confounding. }\end{array}$ \\
\hline $\begin{array}{l}\text { Muscle } \\
\text { strength }\end{array}$ & $\begin{array}{l}\text { SMD }=0.27 \quad 95 \% \text { CI: }-0.26 \text { to } \\
0.80 \\
\text { Heterogeneity }=0 \% p=0.380\end{array}$ & $\begin{array}{l}57 \\
(2 \\
\text { studies })\end{array}$ & $\begin{array}{l}\text { Low } \\
>>\mathrm{OO} \\
\text { Serious } \\
\text { methodological } \\
\text { limitations; } \\
\text { serious } \\
\text { imprecision due } \\
\text { to small sample; }\end{array}$ & $\begin{array}{l}\text { The trial by Palumbo (taichi) listed isometric } \\
\text { knee extension but did not provide the } \\
\text { results (selective reporting). The two other } \\
\text { studies were selective samples -Chopp- } \\
\text { Hurley et al. recruited older employees with } \\
\text { osteoarthritis through advertisement } \\
\text { Granacher lacks information to judge the } \\
\text { trial quality; }\end{array}$ \\
\hline $\begin{array}{l}\text { Balance } \\
\text { (any } \\
\text { measure) }\end{array}$ & $\begin{array}{l}\text { SMD }=1.29 \quad 95 \% \mathrm{CI}:-0.56 \text { to } \\
3.15 \\
\text { Heterogeneity }=81 \% \mathrm{p}=0.021\end{array}$ & $\begin{array}{l}46 \\
(2 \\
\text { studies })\end{array}$ & $\begin{array}{l}\mathrm{Low} \\
>>\mathrm{OOO}\end{array}$ & $\begin{array}{l}\text { Heterogeneity could reflect the differences } \\
\text { of the tool used to measure displacement of } \\
\text { COP; Granacher et al used balance platform }\end{array}$ \\
\hline
\end{tabular}

Page 13/15 
Serious methodological limitations; serious imprecision; inconsistent results

\begin{tabular}{|c|c|c|c|c|c|}
\hline Flexibility & $\begin{array}{l}\text { SMD }=0.50 \\
\text { to } 1.05 \\
\text { Heterogeneity }=0 \% p=0.366\end{array}$ & 95\% CI: -0.05 & $\begin{array}{l}58 \\
\text { (2 } \\
\text { studies) }\end{array}$ & $\begin{array}{l}\text { Low } \\
>>\mathrm{OO} \\
\text { Serious } \\
\text { methodological } \\
\text { limitations; } \\
\text { imprecision; }\end{array}$ & $\begin{array}{l}\text { In both RCT randomisation process were } \\
\text { unclear; studies of small sample size and } \\
\text { high risk of performance bias and selective } \\
\text { reporting }\end{array}$ \\
\hline
\end{tabular}

\section{Supplementary Files}

Supplementary Table 1_ Characteristic of worksite physical activity (PA) interventions delivered to older employees (organised by publication dates)

Supplementary Table 2_ Risk of bias assessment for RCTs and quasi-experiments

Supplementary file 3_. PRISMA checklist Complete

\section{Figures}

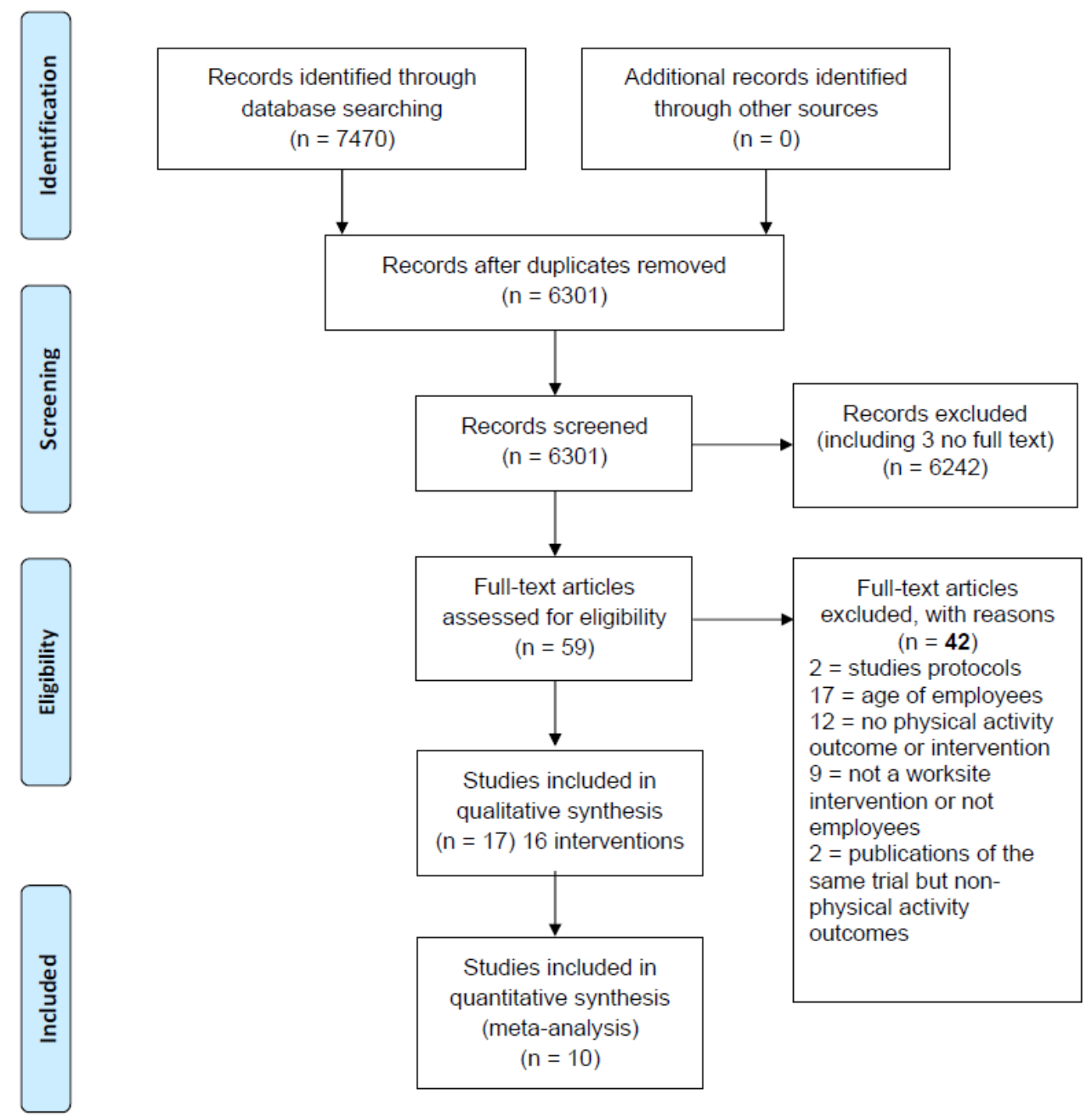

Figure 1

PRISMA flow diagram of selected workplace physical activity intervention studies 

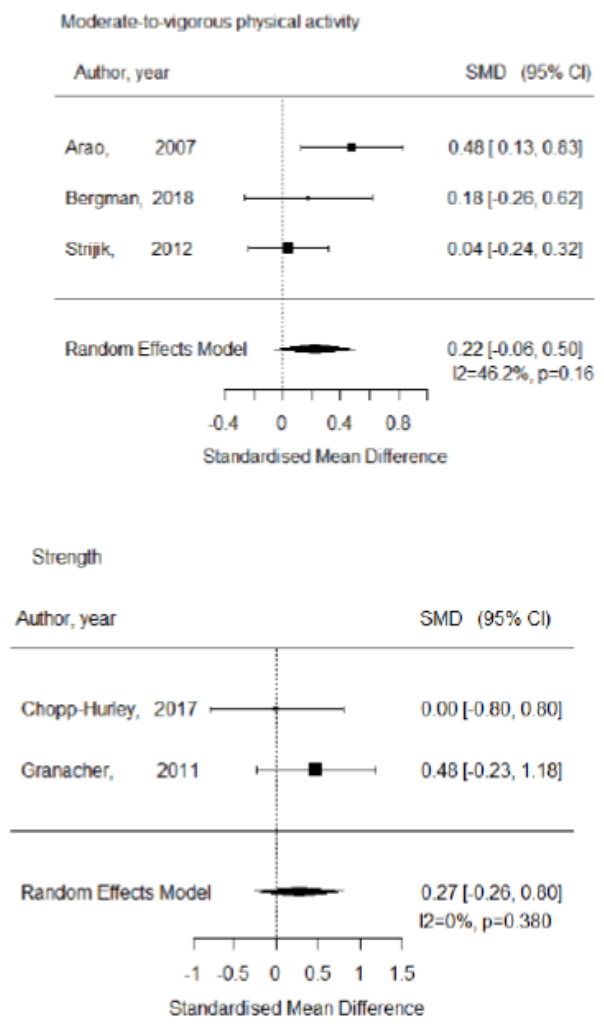

Frequency daylweek

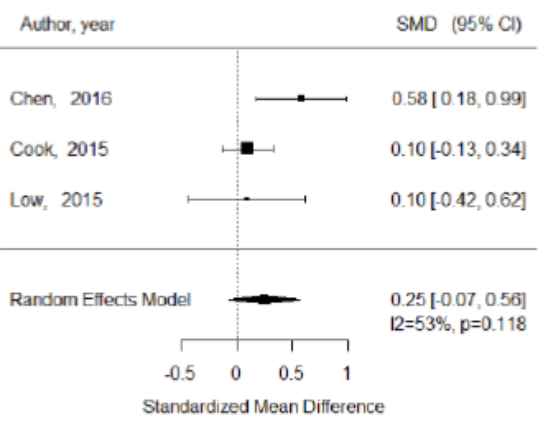

Balance

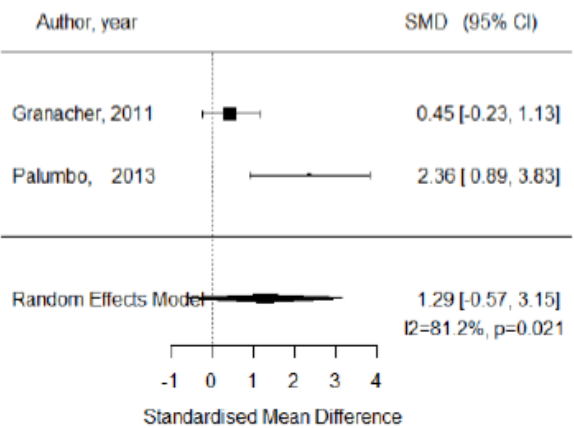

Cardiorespiratory fitness

Author, year SMD $(95 \% \mathrm{Cl})$

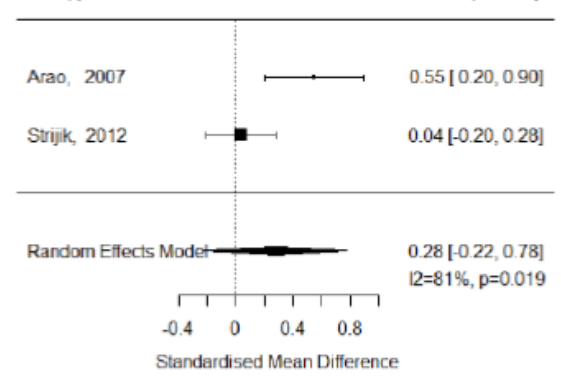

Flexibility

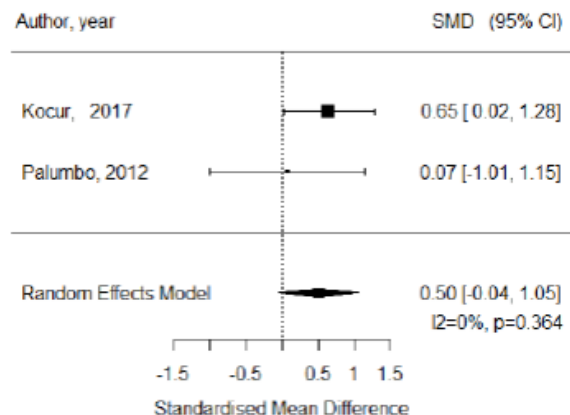

Figure 2

Forest plot of the standardised mean difference (STD) between intervention (right) and control (left) for PA/fitness outcomes

\section{Supplementary Files}

This is a list of supplementary files associated with this preprint. Click to download.

- SupplementaryTable2ROB.docx

- SupplementaryTable1characteristicsofintervention.docx

- PRISMA2009checklistcomplete.doc 